\title{
THE ROLE OF CUSTOMER RELATIONSHIP MANAGEMENT IN INDONESIA BUSINESS
}

\author{
Erna Andajani *) \\ Nurul Badriyah **)
}

\begin{abstract}
Companies need to have tactics to win business competition. One way that can be used by the company is to recognize and understand the customer. Companies that perform customer relationship management will be able to sustain its business. The existence of customers is the driving force of business enterprises in various industries. In business services, the customer can be as an actor and a very crucial business objects. This study aimed to clarify the concept of customer relationship management and serves some research management customer relations in Indonesia. The study also describes the application of customer relationship management the company has done in Indonesia.
\end{abstract}

Keywords: Customer Relationship Management, Customer, Relationship.

\section{INTRODUCTION}

\subsection{Research Background}

In the era of business competition requires companies to change the orientation to customer oriented. The seriousness begins with a customer-oriented company to know and understand the customer. The process of understanding the customer is done through interaction with customers (relationship). Companies that successfully build and maintain customer relationships can sustain its business. The existence of customers is the driving force of the company's business in various industries. In business, especially in services, the customer is a partner to create services and business objects very crusial. Bitner, Brown and Meuter (2000) in Mithas, Krishnan, and Fornell (2005) states still little research into the role and contribution of the implementation of Customer Relationship Management (CRM). This statement inspires researchers to renew the CRM research in the 20th century. Mithas, Krishnan, and Fornell (2005) states that the big companies in America that have successfully implemented CRM and have an impact on customer satisfaction. Mithas, Krishnan, and Fornell (2005) advised to test the effect of CRM on customer satisfaction in the context of individual customers and business customers. Consequences of the implementation of CRM can improve the company's performance is interesting to peruse. Based on the discourse, this study aims to clarify the concept of customer relationship management and serves some customer relationship management research in Indonesia. The study also describes the application of customer relationship management has been done in Indonesia.

\subsection{Research Problem}

Based on the above points of thought, the research problem is how the role of customer relationship management (CRM) in Indonesia Business.

\subsection{Research Purpose}

This research aims to know and examines the role of customer relationship management (CRM) in Indonesia Business by using qualitative approach. 


\section{THEORETICAL FRAMEWORK}

\subsection{Previous Research Studies}

Table 1 CRM Research in Indonesia

\begin{tabular}{|c|c|c|c|c|c|c|}
\hline No & $\begin{array}{c}\text { Author and } \\
\text { Year }\end{array}$ & Methodology & $\begin{array}{c}\text { Research } \\
\text { Object }\end{array}$ & $\begin{array}{c}\text { Independent } \\
\text { Variable }\end{array}$ & $\begin{array}{c}\text { Dependent } \\
\text { Variable }\end{array}$ & Result \\
\hline 1 & $\begin{array}{l}\text { Adnin, Lubis } \\
\text { and } \\
\text { Widayanto } \\
\text { (2013) }\end{array}$ & $\begin{array}{l}\text { Quantitative. } \\
\text { Regression } \\
\text { Linier }\end{array}$ & $\begin{array}{l}\text { Automotive } \\
\text { Repair } \\
\text { Customers in } \\
\text { Semarang }\end{array}$ & $\begin{array}{l}\text { CRM (People, } \\
\text { Process and } \\
\text { Technology) }\end{array}$ & $\begin{array}{l}\text { Customer } \\
\text { Loyalty }\end{array}$ & $\begin{array}{l}\text { CRM has a } \\
\text { significant } \\
\text { effect toward } \\
\text { Customer } \\
\text { Loyalty }\end{array}$ \\
\hline 2 & $\begin{array}{l}\text { Estiningsih } \\
\text { and } \\
\text { Hariyanti } \\
(2013)\end{array}$ & $\begin{array}{l}\text { Quantitative. } \\
\text { Multiple Linier } \\
\text { Regression } \\
\text { linier }\end{array}$ & $\begin{array}{l}\text { Pregnant } \\
\text { women in } \\
\text { Malang }\end{array}$ & $\begin{array}{c}\text { CRM } \\
\text { (People, Process } \\
\text { and Technology) }\end{array}$ & $\begin{array}{l}\text { Customer } \\
\text { Loyalty }\end{array}$ & $\begin{array}{l}\text { CRM has a } \\
\text { significant } \\
\text { effect toward } \\
\text { Customer } \\
\text { Loyalty }\end{array}$ \\
\hline 3 & $\begin{array}{l}\text { Indah and } \\
\text { Devie } \\
(2013)\end{array}$ & $\begin{array}{c}\text { Quantitative. } \\
\text { PLS }\end{array}$ & $\begin{array}{l}\text { Company } \\
\text { Service } \\
\text { Manager in } \\
\text { Surabaya }\end{array}$ & $\begin{array}{c}\text { CRM } \\
\text { (Customer } \\
\text { Satisfaction and } \\
\text { Long Term } \\
\text { Relationship) }\end{array}$ & $\begin{array}{l}\text { Competitive } \\
\text { Advantage } \\
\text { and } \\
\text { Company } \\
\text { Performance }\end{array}$ & $\begin{array}{l}\text { CRM has a } \\
\text { significant } \\
\text { effect } \\
\text { Competitive } \\
\text { Advantage } \\
\text { and Company } \\
\text { Performance }\end{array}$ \\
\hline 4 & $\begin{array}{c}\text { Ersi and } \\
\text { Semuel. } \\
(2014)\end{array}$ & $\begin{array}{l}\text { Quantitative. } \\
\text { PLS }\end{array}$ & $\begin{array}{l}\text { SMEs Flour } \\
\text { in East Java }\end{array}$ & $\begin{array}{c}\text { CRM } \\
\text { (Infrastructure } \\
\text { IT, Human } \\
\text { Resources } \\
\text { Knowledge, } \\
\text { Business } \\
\text { Architecture) }\end{array}$ & $\begin{array}{l}\text { Satisfaction } \\
\text { and Loyalty }\end{array}$ & $\begin{array}{c}\text { CRM has a } \\
\text { significant } \\
\text { effect } \\
\text { Customer } \\
\text { Satisfaction. } \\
\text { While at the } \\
\text { same time, } \\
\text { CRM don't } \\
\text { Effect on } \\
\text { Customer } \\
\text { Loyalty }\end{array}$ \\
\hline 5 & $\begin{array}{l}\text { Ellynia and } \\
\text { Tjhin } \\
(2014)\end{array}$ & $\begin{array}{l}\text { Applied } \\
\text { Research }\end{array}$ & $\begin{array}{l}\text { WhatsApp, } \\
\text { WeChat, Line } \\
\text { and Kakao } \\
\text { Talk users } \\
\text { in Indonesia }\end{array}$ & \begin{tabular}{|c} 
eCRM \\
(User Friendly, \\
Smartphones, \\
Operation System \\
Used and User \\
Interface)
\end{tabular} & & $\begin{array}{l}\text { The most } \\
\text { widely } \\
\text { used } \\
\text { application is } \\
\text { the Line }\end{array}$ \\
\hline
\end{tabular}


Continue

\begin{tabular}{|c|c|c|c|c|c|c|}
\hline No & $\begin{array}{c}\text { Author and } \\
\text { Year }\end{array}$ & Methodology & $\begin{array}{c}\text { Research } \\
\text { Object }\end{array}$ & $\begin{array}{c}\text { Independent } \\
\text { Variable }\end{array}$ & $\begin{array}{c}\text { Dependent } \\
\text { Variable }\end{array}$ & Result \\
\hline 6 & Carissa, & Applied & Distro & Proses & & Distro \\
& Fauzi and & Research & Customers in & CRM \\
& Kumadji & & Malang & Customer Data \\
& $(2014)$ & & Collection, & & & implemented \\
& & & Analysis, \\
and & & & $\begin{array}{c}\text { CRM and } \\
\text { some } \\
\text { suogestions }\end{array}$ \\
\hline
\end{tabular}

Source: Adnin, Lubis and Widayanto (2013); Estiningsih and Hariyanti (2013); Indah and Devie (2013); Ersi and Semuel (2014); Ellynia and Tjhin (2014); Carissa, Fauzi and Kumadji (2014).

\subsection{Theoretical Framework}

\subsubsection{Customer Relationship Management (CRM)}

Buttle and Maklan (2015) describes the meaning of the ' $R$ ' of CRM stands for 'relationship'. A relationship is composed of a series of interactive episodes between dyadic parties over time. Relationships can be meant as the company's relationship with the customer or the company's relationships with suppliers. Understanding the concept of this relationship is easily understood and can be interpreted in a broader sense. The longer the relationship, the two sides better understand each other. In the process of relationship that gives rise to trust and commitment between the two parties. Both of these factors lead to increasingly close relationship and deep.

The concept of customer relationship management has been known since the early 1990s (Buttle and Maklan, 2015). During the development of the concept of customer relationship management have emerged various definitions of CRM are summarized in Table 1. The CRM can be defined as the process of interaction between companies and customers. In the process of interaction is built and nurtured relationships with customers. The process of building and maintaining customer relationships are managed by firms for the benefit of long-term corporate profits. In the process of CRM, companies identify, acquire and retain customers. The Company seeks to create and deliver customer value. The company's aim that customers survive and lead to customer loyalty. Today the CRM process facilitated by information technology. IT is integrated into the company help exercising effective enterprise CRM. The main objective of CRM to improve the long-term and profitable for the company through understanding of customer behavior better. On the other hand, the CRM can be considered as the company's business strategy. Companies have to change the orientation of companies from marketing to customer-centric. By understanding the needs and desires of customers better impact on customer satisfaction. This will provide benefits and income in the long term and sustainable.

The concept of CRM can be reviewed in three types, namely: strategy, operational and analytical (Buttle and Maklan, 2015). In the aspect of strategic state that CRM is core customercentric business strategy that aims at winning and keeping profitable customers. Company oriented thinking to create customer value and delivering better than competitors. Type Operational CRM focuses predominantly on the automation of customer-facing process such selling, marketing and customer service. In operational CRM companies often use a software application (marketing automation, sales force automation and service automation) are integrated. The use of CRM application aims to enhance customer value and facilitate the company's work system. Analytical CRM is the process through which organization customer-related transform the data into actionable insight for either strategic or tactical purposes. Analytical CRM focus on acquiring customer data. The customer data is processed in a manner to increase the value of the customer and the company. 
Based on table 1, it is interesting to study the concept of CRM. Many companies have implemented CRM in business processes. In Indonesia, CRM research has also been done in the form of basic and applied research. CRM is often associated with customer satisfaction and loyalty as a form of consequence. Customer satisfaction is feeling happy or disappointed someone who is the result of a comparison of perceptions of product performance and expectations (Kotler, 2010). Customer satisfaction arises when a customer interacts with the company. In the context of a company engaged in the service of customer satisfaction occurs after the product is delivered services. Satisfied customers tend to be loyal customers. Customer loyalty is a form of customer behavior in the activity of purchasing goods or services over and over, buying products other products offered the same manufacturer and recommend goods or services to others consistently (Tjiptono and Chandra, 2011). Companies that implement the CRM can address the customer in the context of the customer (end-user) or supplier. The relationship between CRM with customer satisfaction and loyalty can apply in the context of the customer (end-user) or supplier.

Buttle (2004) states that there are four conditions in the development and implementation of CRM strategy at the company, among other things: leadership and corporate culture, information technology and data, human resources and business processes. Coltman, Devinney and Midgley (2009) in Ersi and Samuel (2014) expressed the same thing that the IT infrastructure, knowledge of HR and business architecture can support the company's CRM. Measurement of CRM can be summed up in three main points namely processes, human resources and technology. The process includes the systems and procedures used to identify and establish a relationship with the customer. HR aspect explains the company's employees as a CRM implementer. In the service business, employees determine the success of the business. Technology used to help accelerate and optimize processes and employees in CRM activity. Technology is a tool supporting the complementary value-added CRM and enterprise customers.

\section{Table 2 Definitions of CRM}

\begin{tabular}{|c|l|}
\hline No. & \multicolumn{1}{|c|}{ Definition of CRM } \\
\hline 1 & $\begin{array}{l}\text { CRM is an information industry term for methodologies, software and usually internet } \\
\text { capabilities that help an enterprise manage customer relationships in an organized way. }\end{array}$ \\
\hline 2 & $\begin{array}{l}\text { CRM is the process of managing all aspects of interaction a company has with its } \\
\text { customers, including prospecting, sales and service. CRM applications attempt to } \\
\text { provide insight into and improve the company/customer relationship by combining all } \\
\text { these views of customer interaction into one picture. }\end{array}$ \\
\hline 3 & $\begin{array}{l}\text { CRM is an integrated approach to identifying, acquiring and retaining customers. By } \\
\text { enabling organizations to manage and coordinate customer interactions across multiple } \\
\text { channels, departments, lines of business and geographies, CRM helps organizations } \\
\text { maximize the value of every customer interaction and drive superior corporate performance. }\end{array}$ \\
\hline 4 & $\begin{array}{l}\text { CRM is an integrated information system that is used to plan, schedule and control the pre- } \\
\text { sales and post-sales activities in an organizations. CRM embraces all aspects of dealing } \\
\text { with prospects and customers, including the call center, sales force, marketing, technical } \\
\text { support and field service. The primary goal of CRM is to improve long-term growth and } \\
\text { profitability through a better understanding of customer behavior. CRM aims to provide } \\
\text { more effective feedback and improved integration to better gouge the return on investment } \\
\text { (ROI) in these areas. }\end{array}$ \\
\hline 5 & $\begin{array}{l}\text { CRM is business strategy that maximizes profitability, revenue and customer satisfaction by } \\
\text { organizing around customer segments, fostering behavior that satisfaction } \\
\text { customers, and implementing customer-centric processes. }\end{array}$ \\
\hline
\end{tabular}

Source: Buttle and Maklan (2015) 


\section{RESEARCH METHOD}

\subsection{Research Design}

Descriptive research is used to analyze and present data that is qualitative. Moleong (2000: 3) defined qualitative as "a procedure that produces descriptive data in the form of written or oral words and observable persons and actors". Qualitative research used in this research to tell, interpret and describe data that writer get from observation, interview and documentation. This research uses observations and documentation of previous research about the implementation CRM in Indonesia Business.

\subsection{Type of Data}

The data obtained are secondary data. Secondary data is data obtained not from respondents or resource persons directly. Researcher uses observation (method of collecting data by deliberate and systematic study of social phenomena and natural phenomena by way of observation and recording) and documentation (method of collecting data by holding records from the archive that has to do with the problems studied by the author) as their data collection method.

\section{RESEARCH RESULT AND ANALYSIS}

\subsection{Research Discussion}

This study discusses the CRM basic and applied research that has been done in Indonesia. Table 2 presents the CRM research using quantitative methodology with multiple linear regression and SEM as well as applied research. Research of Adnin, Lubis and Widayanto (2013), Estiningsih and Hariyanti (2013), Ersi and Samuel (2014) examined the effect of CRM variable to variable customer loyalty and customer satisfaction. Good customer relationship management have an impact on customer satisfaction. Customer satisfaction affects customer loyalty. In the study Adnin, Lubis and Widayanto (2013), Estiningsih and Hariyanti (2013) shows the influence CRM directly into customer loyalty. When companies interact with customers and there is a relationship, it can be said to occur when customer satisfaction. Companies engaged in the service has been duly perform CRM. Services products occurs when there is interaction between the customer and service provider companies. Type operational CRM focuses more on the way companies build relationships with customers.

Indah and Devie (2013) examine the effect of CRM on competitive advantage and performance of companies that provide significant results. In Indah and Devie (2013) uses the measurement of CRM in the context of business to business. CRM is measured through technology that supports CRM, skills and abilities and attitudes of people who control the CRM and the processes used by the company in accessing and interacting with customers to create new value and satisfaction. Strategic CRM objectives to build a CRM company to create and deliver maximum customer value and better than the competition. Companies can develop relationships with corporate customers (individual) or business customers (companies). In the context of relations mengelolaan business customers more emphasis on the sustainability of the company's strategic business.

Based on the table of previous research studies above its shws that the study of Ellynia and Tjhin (2014); Carissa, Fauzi and Kumadji (2014) revealed CRM applied research. While Ellynia and Tjhin (2014) examined the implementation of CRM companies are using electronic CRM (eCRM) on users WhatsApp, WeChat, Line and Kakao Talk in Indonesia. Type CRM used in Ellynia and Tjhin (2014) is an operational CRM with a focus on customer touch points. Customer touch points can have contact with customers through electronic media. WeChat app, Line and Kakao Talk can be used for enterprise mobility in a relationship with the customer. WhatsApp application does not focus on establishing relationships with customers because this application prioritizes privacy of its users. Carissa, Fauzi and Kumadji (2014) examined the implementation of CRM to improve customer loyalty distributions in Malang. This research is complex enough that begins by 
telling the process of implementing CRM distributions, identify and explain the impact and CRM implementation obstacles. All of the process aims to increase customer loyalty. Directions CRM presented in Carissa, Fauzi and Kumadji (2014) for the strategic CRM. This is in accordance with one of the definitions of CRM (Buttle and Maklan, 2015) that CRM is a strategic business that maximizes profitability, revenue and customer satisfaction. When consumers are satisfied will lead to customer loyalty. Carissa, Fauzi and Kumadji (2014) also discussed the analytic CRM with an evaluation of the implementation of CRM distributions.

The results of the evaluation include: commitment to the implementation of CRM should be understood by the whole structure of the company, the existence of a clear definition and objectives are structured from the implementation of CRM, there needs to be engagement with customers, more focus on the business instead of the technology used during the operation, distributions should have a team that focuses on addressing customer and engage with customers appropriately targeted and effective.

\section{RESEARCH CONCLUSION AND RECOMMENDATION}

\subsection{Conclusion}

Based on the discussion and description above it can be concluded that the concept of CRM has been applied in many local companies in Indonesia. The concept of CRM is not limited in the context of individual customers but can be applied also for business customers. Implementation of CRM in local companies in Indonesia can be seen from the perspective of strategic, operational and analytic. Also found a consistent measurement of CRM processes, human resources and technology to basic research. Measurements CRM on applied research more diverse depending on the purpose of research focus to solve the problems of practice.

\subsection{Recommendation}

This study contributes to expand the concept and application of the relevant researchers in local companies CRM Indonesia. In the real business practice of CRM provide long-term benefits for companies that implement CRM. Limitations of this study to the discussion of CRM research in 2013-2014 and amounted to 6 research. Expected future studies can be developed to examine the foreign companies operating in Indonesia with more diverse research objects. It may be advisable to do research that discuss other variables related to CRM such as word-of-mouth, customer retention and customer experience.

\section{REFERENCES}

Adnin, Rizqi Janati. Lubis, Nawazirul dan Widayanto. 2013. Pengaruh Customer Relationship Management Terhadap Loyalitas Pelanggan PT. Nasmoco Pemuda Semarang. Diponegoro Journal of Social and Politic of Science Tahun 2013, 1-8, available at http://ejournal-s1.undip.ac.id/index.php/

Buttle, Francis. 2004. Customer Relationship Management Concept and Tools. Bayumedia, Malang

Buttle, Francis dan Maklan, Stan. 2015. Customer Relationship Management Concept and Technology $3^{\text {rd }}$. Routledge 711 Third Avenue, New York, NY 10017

Dhingra, Manish dan Dhingra, Vashali. 2013. Determinants of electronic customer relationship management (e-CRM) for customer satidfaction in banking sector in India. African Journal of Business Management Vol. 7 (10), 762-768.

Dyche J.2001. The CRM Handbook: A Business Guide to Cusstomer Relationship Management. Addison- Wesley, Boston, MA. 
Ellynia dan Tjhin, Viany Utami. 2014. Penerapan Customer Relationship Management (CRM) pada Aplikasi Pengiriman Pesan Instan Studi Kasus: WhatsApp, WeChat, Line, KakaoTalk. Ultima InfoSys vol.V no. 1 Juni 2014, 20-26.

Ersi, Dzikiryati Yuni dan Semuel, Hatane. 2014. Analysis CRM, Kepuasan Pelanggan dan Loyalitas Produk UKM berbasis Bahan Baku Terigu di Jawa Timur. Jurnal Manajemen Pemasaran vol.8 no.1 April 2014:1-8. DOI: 10.9744/pemasaran.8.1.1-8.

Estiningsih, Agnes Widayu dan Hariyanti, Tita. 2013. Pengaruh Customer Relationship Management terhadap Loyalitas Ibu Hamil pada Pelayanan Persalinan (Studi di RS Hermina Tangkubanprahu Malang). Jurnal Aplikasi Manajemen Vol.11 nomor 2 Juni 2013

Indah, Purnama Dewi dan Devie. 2013. Analisa Pengaruh Customer Relationship Management Terhadap Keunggulan dan Kinerja Perusahaan. Business Accounting Review vol.1 no 2.

Kotler, P. 2010. Manajemen Pemasaran di Indonesia: Analisis, Perencanaan, Implementasi dan Pengendalian. Salemba Empat, Jakarta.

Mithas, Sunil. Krishnan, M.S dan Fornell, Claes. 2005. Why Do Customer Relationship Management Applications Affect Customer Satisfaction? Journal of Marketing vol. 69 (October 2005), 201-209.

Tjiptono, Fandy and Gregorius Chandra. 2011. Service, Quality and Satisfaction $3^{r d}$. Andy, Yogyakarta.

*) Erna Andajani, State University of Surabaya

**) Nurul Badriyah, Islamic University of Lamongan 